\title{
Jebel Qatrani as Geotourism Sites in Egypt: An Exploratory Study
}

\author{
Maha Yehia Kamel Abdou ${ }^{1 *}$, Suzan Bakri Hassan², Ghada Mohamed Wafik ${ }^{3}$ \\ Tourism Studies Department, Faculty of Tourism and Hotels, Fayoum University, Fayoum, Egypt
}

\begin{abstract}
This research aims to identify the natural and geological features of Jebel Qatrani and to explore the role of geosite management in enhancing Jebel Qatrani as geotourism sites. A single case study was applied to reach the research aim. This research is based on a qualitative approach to obtain adequate information for achieving the research aim, direct observation was used for data collection. The results revealed that Jebel Qatrani has attractions such as fossils, rocks, mountains, and fossilized trees. The results indicated that Jebel Qatrani is characterized by unique diversity in geological and geomorphological. Jebel Qatrani has a history and geological importance. The results reported that there is a lack of marketing activities or promotion plans for promoting Jebel Qatrani. Also, there is no pamphlet and brochures to provide information to visitors. The results reported that there is a lack of signboard in place, and there is no food and beverage service. This research has several limitations. Firstly, this research focused on one case study of Jebel Qatrani. Secondly, the literature showed there had been a clear lack of prior research studies on geotourism sites in Egypt, in particularly Jebel Qatrani. Future research should address more geosites in Egypt; it also should undertake to test the findings of this research.
\end{abstract}

Keywords: Attraction, Egypt, Geoheritage, Geosite, Geotourism, Management.

\section{INTRODUCTION}

Today, the new trend in modern tourism towards untraditional forms of tourism, such as geotourism, may expand the current offer of destinations [1,2]. So, there are many destinations still isolated and unknown. However, it has become places that need to be explored to meet the tourists' expectations [3]. On the other hand, the knowledge and experience of geological heritage are essential in terms of future renovation [4]. Moreover, the current list of UNESCO geosites will be expanded through unique sites and buildings. So, it is important to combine with different specialties, such as geology and tourism science $[5,6]$.

Tourism destinations are facing a quite complex competitive environment, and this situation may get more complicated in the next years $[7,8]$. Further, the current situation has forced the destinations managers to seek out innovative strategies to achieve customer satisfaction and loyalty $[9,10]$. It is explained that the degree to which a country can benefit from its tourism industry depends largely on this competitive position on the international tourist market [1].

The world pays more attention to the protection and preservation of the landscape and promoting unique sites with a geological and geomorphological feature $[4,11]$. There are many

\footnotetext{
*Correspondence address:

Maha Yehia Kamel Abdou

Email : myk11@fayoum.edu.eg

Address : Dept. Tourism Studies, Faculty of Tourism and Hotels, Fayoum University, Fayoum, Egypt 63514
}

different definitions of geotourism introduced recently. Almost all of them refer to particular geologically or geomorphologically significant places. It means geosites and geomorphosites represent a fundamental resource for geotourism $[12,13]$. Moreover, the geotourism represents a recognition process and giving a broader meaning to geosites, which lead to better and more efficient conservation of geoheritage and geosites [14].

Unfortunately, few sites have been declared as parts of the geological heritage of Egypt, such as Wadi Al-Hitan (Whale Valley), which is included in the list of the UNESCO World Heritage Sites [15]. Also, a study reported that there is a little of attention that given by the tourism industry and the official to the geological features, as well, the availability of tourist guides and brochures in the Egyptian geological sites are rarely found [16]. Therefore, this paper aims to identify the natural and geological features of Jebel Qatrani as geotourism sites and to explore the role of destination management in enhancing Jebel Qatrani as geotourism sites in Egypt.

\section{METHOD \\ Study Area}

Geosites are considered heritage sites that must be conserved for future generations. It is also considered as other natural and human heritage places [17]. The geosites are evidence of climate changes, tectonic evolution, and the related changes in the history of life at the surface of the Earth $[12,18]$. It allows the reconstruction of ancient processes and past climates, environments, and geographies. Also, it 
is important to observe the recent period and current processes and geological features $[19,20]$.

Geosites maybe rank local, regional, national, or global, which depending on the territorial uniqueness of the represented geological phenomena [21]. Furthermore, the rank is determined by the comparison with other geosites known on the local (city), provincial, national (country), or global levels. The determination of geosites investment should be provided. Thus, future geotourism destinations are most likely to be successful [12,22].

Jebel Qatrani is located in Fayoum governorate, Egypt (Fig. 1). It is a mountain that was turned to the attention and care of the UNESCO world of the invaluable fossils containing. It also contains the oldest paved road in the world, as well as different quarries, a mountain of Qatari, which is located in the northern part of the Lake of Qaroun. The area is about $110 \mathrm{~km}$ and a height of about $300 \mathrm{~m}$ and reaches in the eastern part to $350 \mathrm{~m}$, and rises from Lake Qaroun about $400 \mathrm{~m}$, and the distance between him and the lake is not more than 10 $\mathrm{km}[18,23]$.

Qaroun Protected Area includes the Qatrani mountain within its boundaries. A group of primate fossils discovered in Jebel Qatrani of Fayoum is dated to the Eocene age [18]. These finds include a crushed cranium that is the oldest skull found to date of a higher primate [24]. Jebel
Qatrani formation is located at Fayoum Depression about $320 \mathrm{~m}$ thick and consists of siliciclastic conglomerates, sandstones, and sandy mudstones with subordinate carbonaceous shale and carbonates interbed [25]. It is characterized by its variegated white, grey, green, yellow, brown, and red colors. Pedogenesis led to intense geochemical and mechanical alteration of most rocks forming the Jebel Qatrani Formation [18].

Additionally, Jebel Qatrani Formation is composed of variegated sandstones, pebbly sandstones, sandy mudstones, sandy limestones, and shales. The Jebel Qatrani Formation is fossiliferous and particularly have land-animal remains and silicified wood fragments. A thick Oligocene basaltic sheet is known as the Widan El-Faras basalt outcrops locally [17].

\section{Research Data}

A single case study was applied in this research to identify the natural and geological features of Jebel Qatrani as geotourism sites and to explore the role of geosite management in enhancing Jebel Qatrani. This research is based on a qualitative approach since its main aim is to understand the context better from practitioners [26]. To obtain adequate information for achieving the research aim and objectives, one stage was considered to be the most appropriate form of data collection instruments, including direct observation.

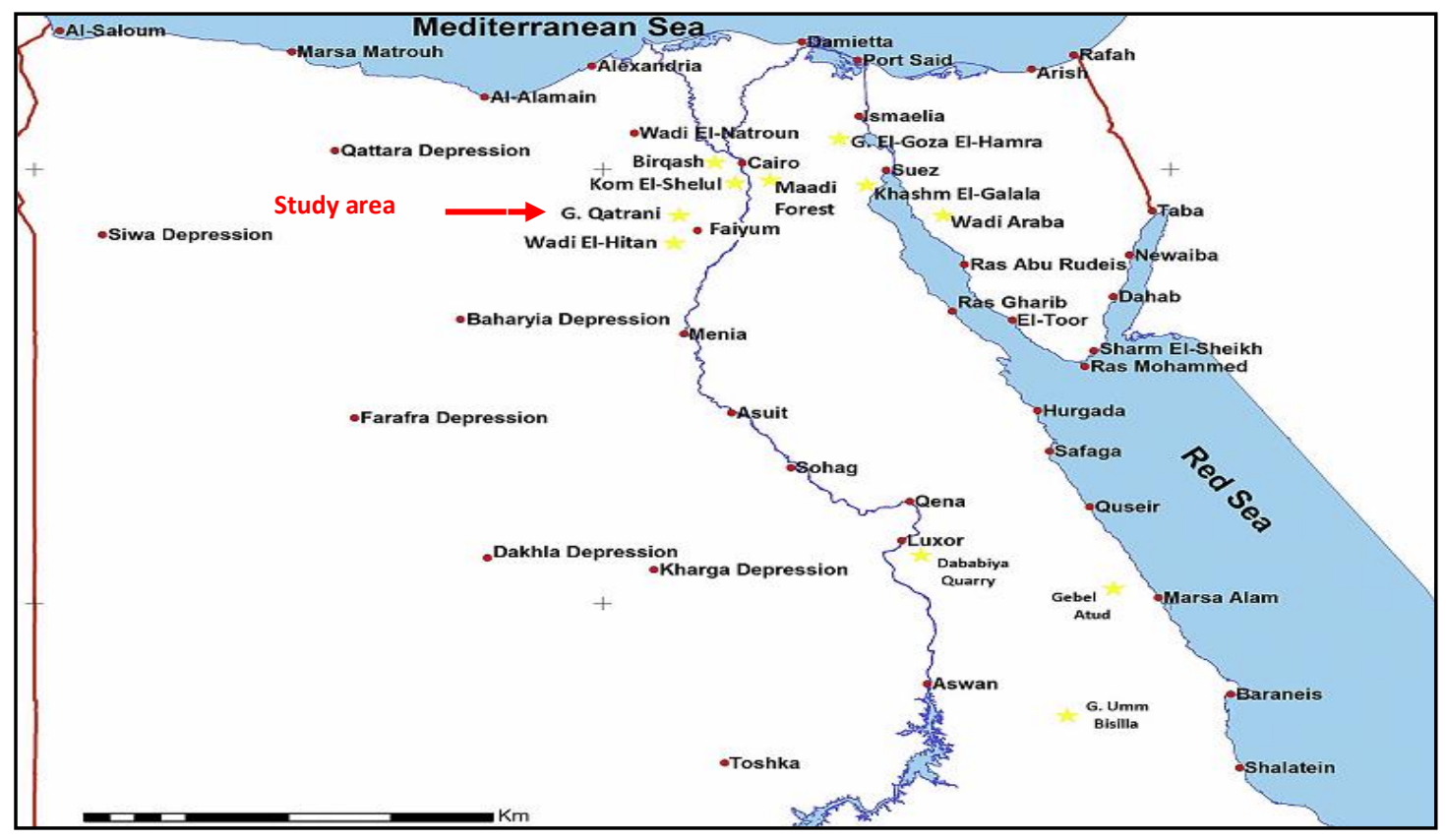

Figure 1. Location of Jebel Qatrani Area in the map of Egypt [18] 
The major final component in the research design is to find specific techniques for data collection. There are two basic sources of data, namely secondary data and primary data. The secondary sources were previous research, books, articles, journals, reports [27]. Primary data is data collected specifically for the research by the researcher [26].

The researcher uses one method for data collection, which is direct observation. During the observation, the researcher took photos of Jebel Qatrani. An observation checklist included the issues related to endowed resources, created resources, site management, and situational conditions in Jebel Qatrani. Secondary methods were by searching in several database sources. It was to investigate previously conducted studies that discussed geotourism sites.

\section{RESULT AND DISCUSSION}

Direct observation reported that Jebel Qatrani features a spectacular view of the color of its rocks and its beautiful natural scenery. It contains a mountain of Qatrani on important geological aspects, which gave the importance of the world. The geological aspect is the numerous amounts of the rarest excavations of vertebrate animals in the world, which are the ancestors of most vertebrate animals. The archaeological site was characterized by the presence of several Pharaonic and Roman monuments. It also has some archaeological quarries of basalt and gypsum, which explain a large era of human life on earth [28].

\section{Endowed resources in Jebel Qatrani}

Endowed resources refer to the geological and natural attraction in Jebel Qatrani. The observation reported that Jebel Qatrani is characterized by all issues in the checklist (Table 1) that discussed below.

Table 1. Endowed resources in Jebel Qatrani

\begin{tabular}{|c|c|c|}
\hline Observation checklist & Yes & No \\
\hline $\begin{array}{l}\text { 1. There is a unique diversity in } \\
\text { geological and geomorphological } \\
\text { forms. }\end{array}$ & $\mathrm{V}$ & \\
\hline $\begin{array}{l}\text { 2. There is an ideal geological features } \\
\text { (cracks and folds). }\end{array}$ & $\mathrm{V}$ & \\
\hline $\begin{array}{l}\text { 3. It has features for different } \\
\text { geological ages. }\end{array}$ & $\mathrm{V}$ & \\
\hline $\begin{array}{l}\text { 4. There are many rocks and colour } \\
\text { mountain. }\end{array}$ & $\mathrm{V}$ & \\
\hline $\begin{array}{l}\text { 5. There are different fossils and } \\
\text { fossilized trees. }\end{array}$ & $\mathrm{V}$ & \\
\hline
\end{tabular}

\section{Diversity of geological forms in Jebel Qatrani}

The observation reported that Jebel Qatrani is characterized by a diversity of natural, geological, and geomorphological features. It also represents a journey through time geological exploration, where visitors can read the events of the deep past, specifically during the confluence of the Eocene and Oligocene. It was where the Jebel Qatrani site tells the story of a journey within the geological era (Fig. 2).

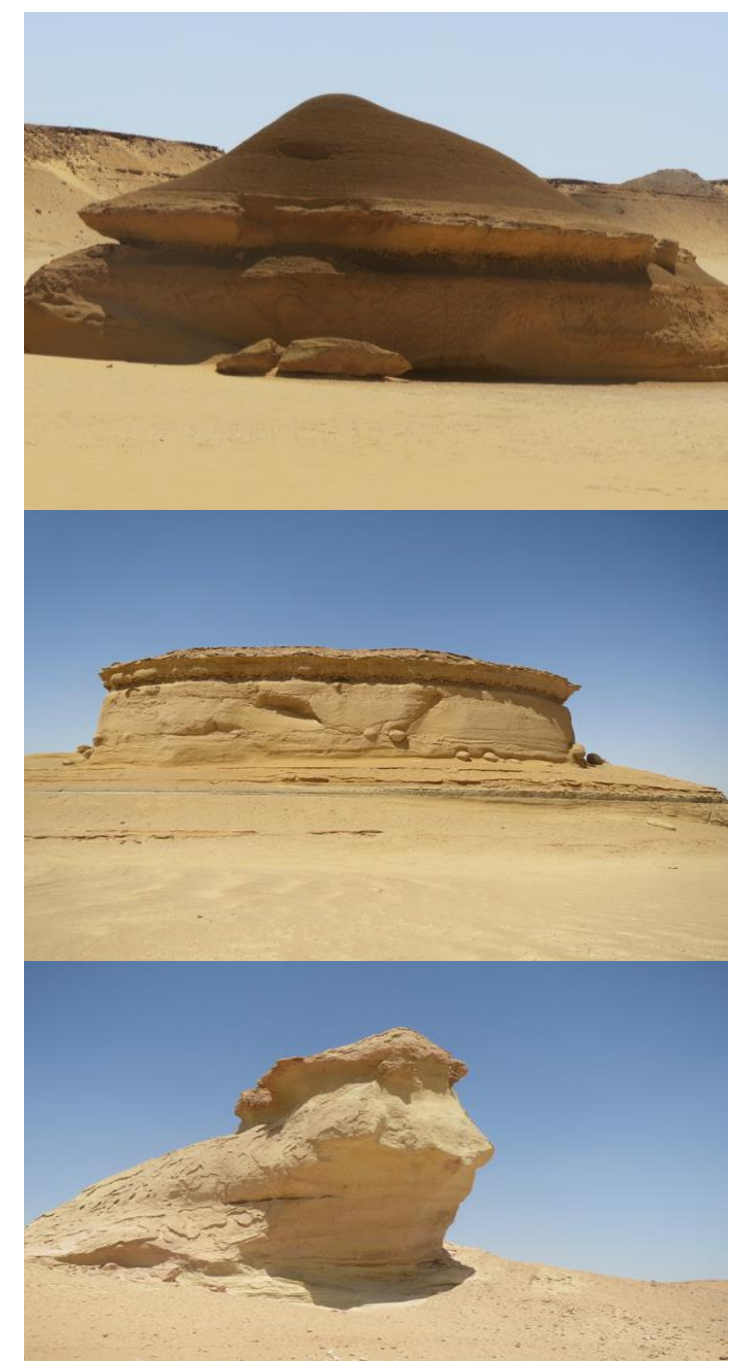

Figure 2. Diversity of geological forms in Jebel Qatrani (Source: Personal Documentation, 2019).

\section{Geological features in Jebel Qatrani}

Geological formations in Jebel Qatrani represent one of the important natural resources because of its great economic value. Hence, it is a treasure of Egypt's natural treasures. In relation to the ideal geological structures in Jebel Qatrani, the observations noted that Jebel Qatrani contains many folds and cracks due to the climate changes during different geological ages (Fig. 3). 

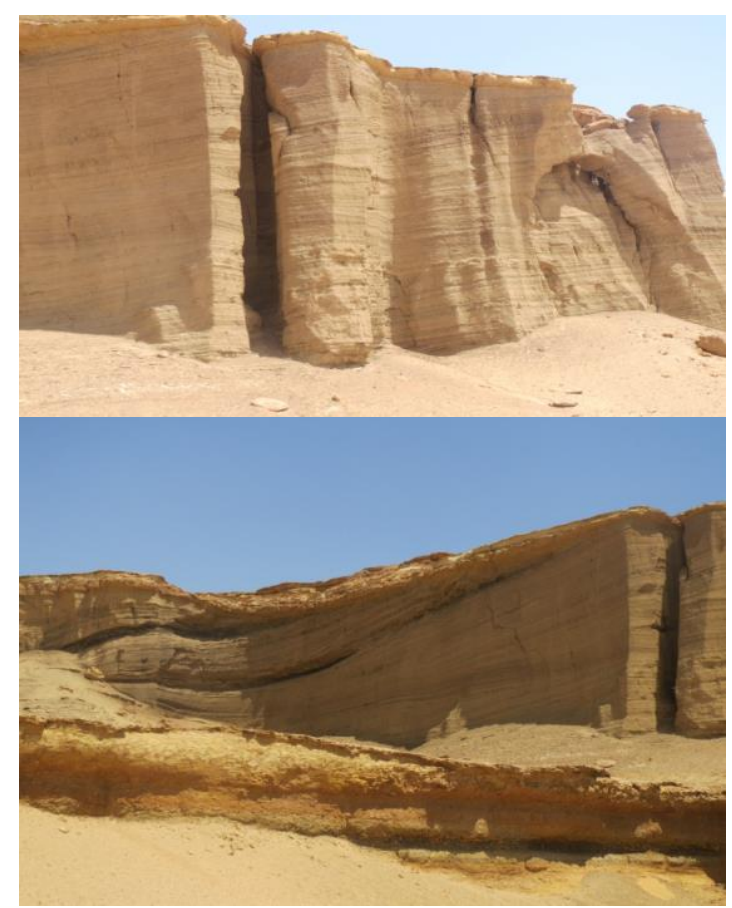

Figure 3. Geological features in Jebel Qatrani (Source: Personal Documentation, 2019)

\section{Geological Ages in Jebel Qatrani}

In terms of geological ages, it has evidence back to Eocene and Oligocene age. The observation noted that Jebel Qatrani was showing a geological change in different geological eras and the climate change through millions of years (Fig. 4).

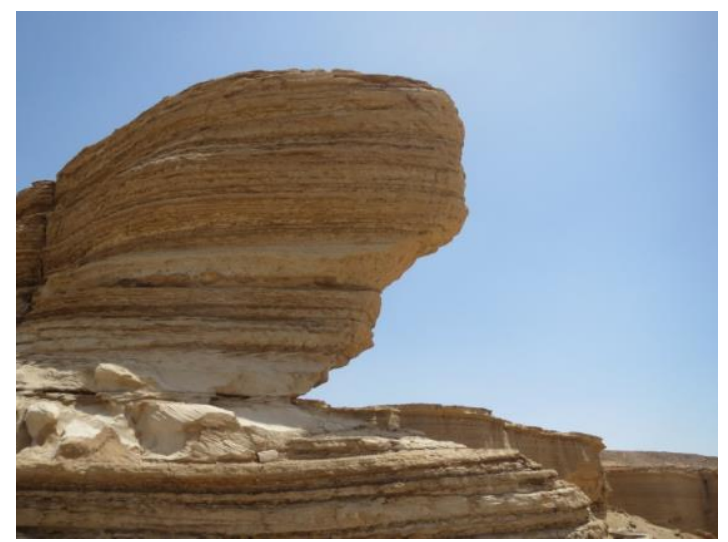

Figure 4. Geological ages in Jebel Qatrani (Source: Personal Documentation, 2019)

\section{Rocks in Jebel Qatrani}

The observation found there is several form of rock in Jebel Qatrani, which were formed by the climatic changes. The different forms of rock were added an aesthetic feature to Jebel Qatrani (Fig. 5).

\section{Colour Mountain in Jebel Qatrani}

The observation noted that Jebel Qatrani is characterized by its spectacular view and the colours of its mountains. For example, the Red Mountains are made up of iron oxides, while the White Mountains were made up of limestone and Black Mountains consist of basalt (Fig. 6).

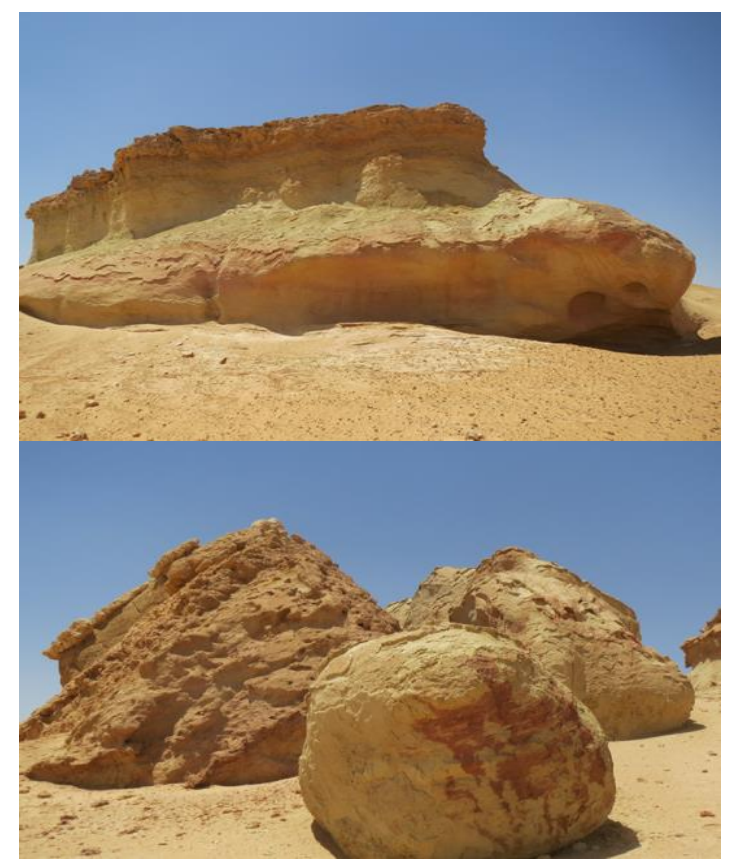

Figure 5. Illustration of the rocks in Jebel Qatrani Area (Source: Personal Documentation, 2019)

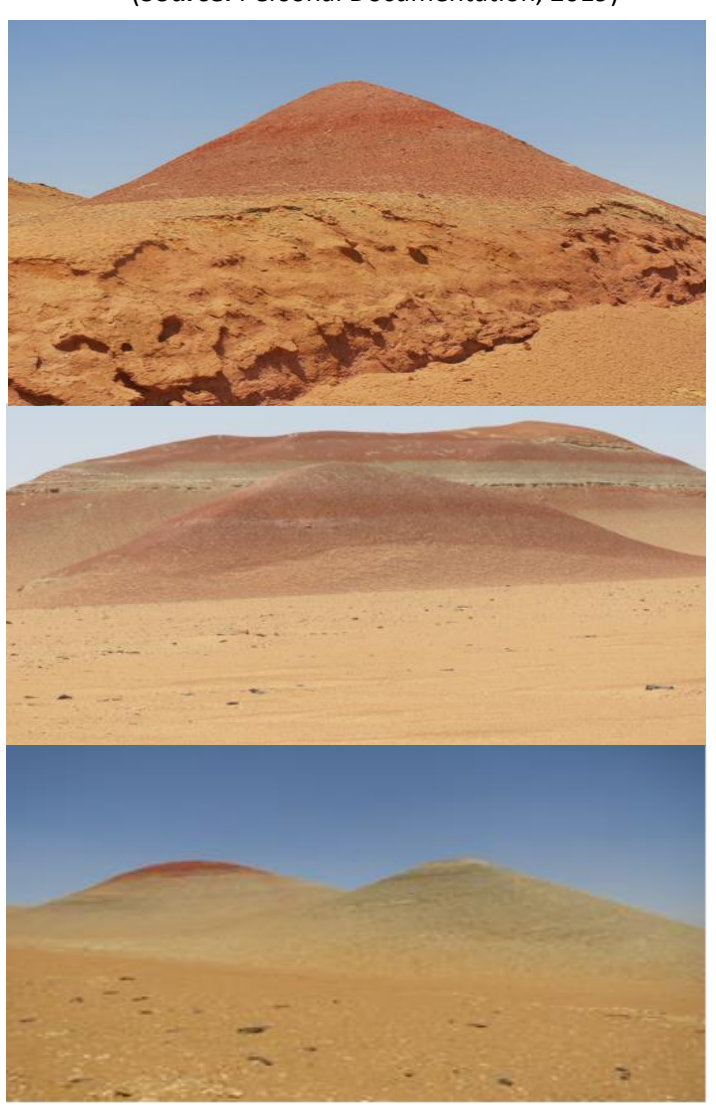

Figure 6. Colour Mountain in Jebel Qatrani (Source: Personal Documentation, 2019) 
Widan El Faras and Basalt Mine in Jebel Qatrani

The observation noted that Widan El-Faras basalt consists of several individual lava flows of early Oligocene capping extensive deposits of sandstone, mudstone, and some limestone that form Qatrani Formation. As well as, the locality of Widan El-Faras, it found the basalt mine area behind Widan el Faras mountain of (upper area of the Gebel Qatrani) (Fig. 7).

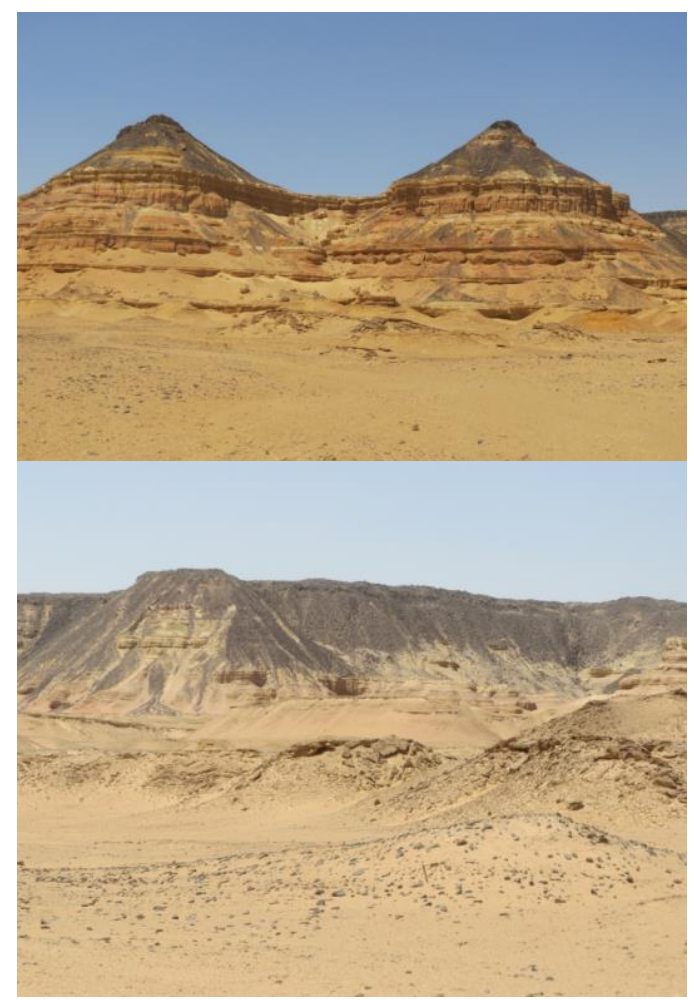

Figure 7. Widan el Faras and Basalt Mine in Jebel Qatrani (Source: Personal Documentation, 2019)

The World's Oldest Road

The road was built for moving blocks of basalt from the Widan El-Faras mines to the shore of the ancient Lake Moeris, the bigger ancestor of Lake Qaroun. The road ended in a quay not far from Qasr Al-Sagha Temple, an Old Kingdom temple still standing north of Lake Qaroun (Fig. 8) [28].

Open Air Museum in Jebel Qatrani

The Jebel Qatrani Open Air Museum is located inside the Petrified Forest area, the north of Lake Qaroun few kilometers from Jebel Qatrani and the ancient basalt quarries. The museum was built in early 2018. The most important exhibits in the museum are including the Petrified that considered one of the most famous petrified forests in the world. The Petrified Forest is home to 35 million years old (Fig. 9) and Arsinoitherium (Fig. 10). The direct observation found that there are different types of fossils in Jebel Qatrani, such as Sirenia (Fig. 11) and Eocene snake (Fig. 12), Masracetus Whale.

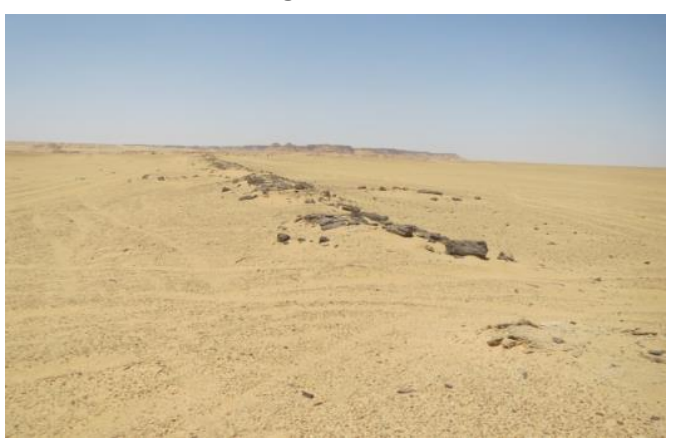

Figure 8.The world's oldest road in Jebel Qatrani (Source: Personal Documentation, 2019)

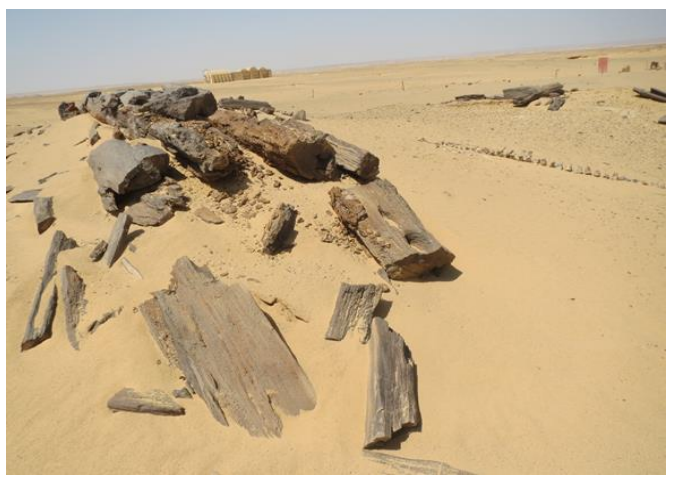

Figure 9. Petrified Forest in Jebel Qatrani (Source: Personal Documentation, 2019)

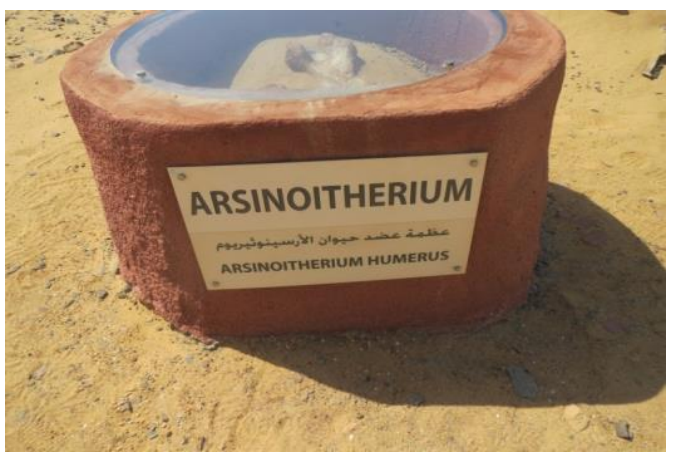

Figure 10. Arsinoitherium in Jebel Qatrani (Source: Personal Documentation, 2019)

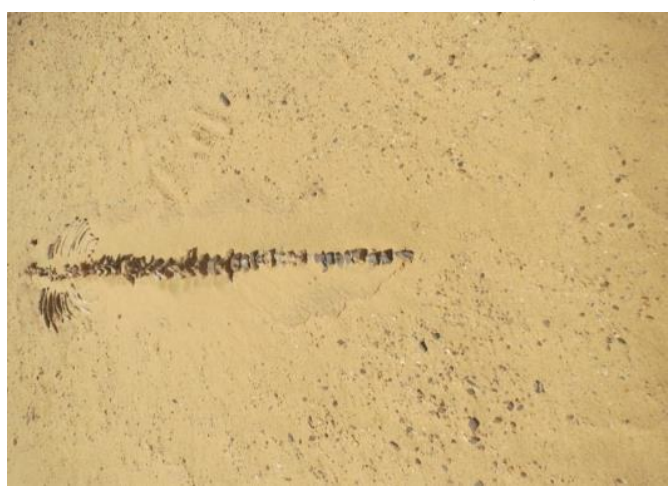

Figure 11. Sirenia in Jebel Qatrani (Source: Personal Documentation, 2019) 


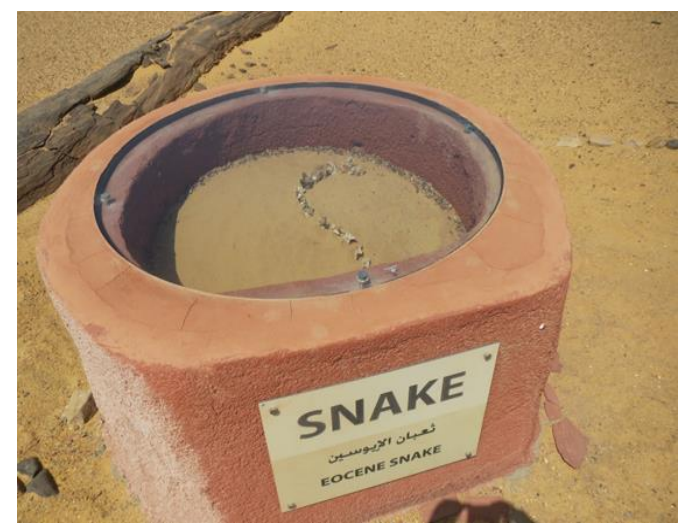

Figure 12. Eocene snake in Jebel Qatrani (Source: Personal Documentation, 2019)

Created resources in Jebel Qatrani

In the created resources, the observation found the transportation facilities and accessibility into the Jebel Qatrani is difficult, it is due to lengthy travel times, high costs and entry barriers. It also noted that there is no public transportation to Jebel Qatrani, the area of Jebel Qatrani need private transportation with Fourwheel drive cars.

The observation noticed that there is no pamphlets and brochures in Jebel Qatrani. However, it found that there is a recreational activity such as camping. In addition, there are no shops or places for selling souvenirs to visitors. The observations showed that there is no medical service or ambulance point within or near Jebel Qatrani. It observed that there is a telephone network in someplace, and it is not in other places that affect the communication between visitors and tourist groups (Table 2).

Table 2. Created resourcesin Jebel Qatrani

\begin{tabular}{|c|c|c|}
\hline Observation checklist & Yes & No \\
\hline $\begin{array}{l}\text { 1. There are transportation facilities } \\
\text { available to visitors to Jebel Qatrani. }\end{array}$ & & $\sqrt{ }$ \\
\hline $\begin{array}{l}\text { 2. There are maps, pamphlets and } \\
\text { brochures for Jebel Qatrani. }\end{array}$ & & $\checkmark$ \\
\hline $\begin{array}{l}\text { 3. There are recreational activities in } \\
\text { Jebel Qatrani such as camping. }\end{array}$ & $\sqrt{ }$ & \\
\hline $\begin{array}{l}\text { 4. There are places to sell souvenirs in } \\
\text { Jebel Qatrani. }\end{array}$ & & $v$ \\
\hline $\begin{array}{l}\text { 5. There are medical services within or } \\
\text { near Jebel Qatrani. }\end{array}$ & & $\checkmark$ \\
\hline $\begin{array}{l}\text { 6. There is a communication network } \\
\text { within Jebel Qatrani. }\end{array}$ & $\mathrm{v}$ & \\
\hline $\begin{array}{l}\text { 7. There is food and beverage service } \\
\text { within or near Jebel Qatrani. }\end{array}$ & & $\checkmark$ \\
\hline $\begin{array}{l}\text { 8. Accommodation services are available } \\
\text { near Jebel Qatrani. }\end{array}$ & $\sqrt{ }$ & \\
\hline $\begin{array}{l}\text { 9. There are signs in the roads and tracks } \\
\text { to Jebel Qatrani. }\end{array}$ & $\mathrm{V}$ & \\
\hline 10. Level of cleanliness of Jebel Qatrani. & 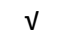 & \\
\hline 11. There are bathrooms in Jebel Qatrani. & & $\sqrt{ }$ \\
\hline
\end{tabular}

The observation found that there is not outlet for serving food and beverage to the visitors in Jebel Qatrani but there are hotels and restaurants provided food and beverage facilities such as, Byoum hotel and hotels/restaurants in Tunis Village. As well as, there is accommodation service near Jebel Qatrani.

In terms of signboards and tracks in Jebel Qatrani, the observation results found that there is a lack of road signs and tracks signs in the place, which might cause the visitors and tourists to get lost in the desert. It is found only in the main road and the entrance to Jebel Qatrani.

Although the area of Jebel Qatrani is cleanliness and pure, there are no garbage cans in the area of Jebel Qatrani. The observation found that the bathrooms were only found in the management building at the main entrance of Jebel Qatrani and the Open Air Museum.

\section{Site Management and Situational Conditions in Jebel Qatrani}

The environmental regulation refers to preserve the geosites such as; prevent collect, remove, or damage any material in the geosites. It also prevents collecting any fossils and walking inside the tracks and follows the instructions in the geosite. However, the observation noted that there are regulations to protect the environment within Jebel Qatrani, but not all visitors following these regulations. Because there is no one provided information or explain the guidelines and the instructions to visitors. For that, Jebel Qatrani management should allocate staff to accompany the visitors. The observation reported that the area of Jebel Qatrani did not have any promotion activities (Table 3 ).

Table 3. Site Management and Situational Conditions in Jebel Qatrani

\begin{tabular}{lll}
\hline \multicolumn{1}{c}{ Observation checklist } & Yes & No \\
\hline 1. There are regulations to protect & $\mathrm{V}$ & \\
the environment within Jebel & & \\
Qatrani. & $\mathrm{V}$ \\
2. There is a variety of marketing \\
activities used for Jebel Qatrani.
\end{tabular}


During the observation, the researcher found that Jebel Qatrani accessible from all directions. So, anybody can enter at any time and get out at any time without being controlled. Also, the observation found that there is no accurate count of the number of visitors to the site, and no one counts them. It also observed that there is no ticket for entering Jebel Qatrani. The observation noticed that visitors are not accompanied by staff in Jebel Qatrani. As well as, there is a lack of security procedures in place to protect visitors in Jebel Qatrani (Table 3).

\section{DISCUSSION}

Direct observation aimed to identify the natural and geological features in Jebel Qatrani and to explore the actual situation to use Jebel Qatrani as a geotourism site. The observation checklist was depended on the literature review and all points in the list identified in the study of [9]. The site of Jebel Qatrani is proposed to be inscribed under the natural criterion of the operational guidelines for World Heritage 2005. The nature conservation sector of the Ministry of Environment identified the Jebel Qatrani as a fossil site of major importance from the scientific point of view and one of the most important site in the whole African continent, in terms of fossil richness in its management plan $[28,29]$.

\section{Endowed resources in Jebel Qatrani}

According to the literature reviews, geosites differ by their unique geological features, which determine their value for science, education, and tourism [30,31]. Furthermore, it was mentioned that the geosites showing the links between the geological characteristics and the biotopes (ecological interest) [32]. As well, the geosites involved the geological and geomorphic features, which contribute to the formation of the sense of place for any geosite [33]. More specifically, these features include different kinds of landscapes, landforms, rock outcrops and types, sediments, soils and crystals [24,32].

The observation data confirmed literature reviews that the Jebel Qatrani area is characterized by a diversity of natural, geological, and geomorphological features. It also found that Jebel Qatrani is characterized by its spectacular view and the colours of its rocks and its natural landscapes. The red mountains are made up of iron oxides, while the White Mountains are made up of limestone. In addition, black mountains consist of basalt.
On the other hand, the observation results matched with the previous study that the geosite representing the geological heritage of the Earth [34]. Key characteristics of selected geosites have good potential for increasing the awareness of geological heritage $[24,35]$.

\section{Created resources in Jebel Qatrani}

However, the literature review reported that infrastructure plays an important role in site management. The geoheritage and geosites have confronted many challenges, such as the accessibility and infrastructure issues, and the lack of sustainability of geoheritage $[36,37]$. With regard to that, observation indicated that the transportation facilities and accessibility into the Jebel Qatrani area are difficult. It is due to lengthy travel times, high costs, and entry barriers. It is due to lengthy travel times, high costs and entry barriers. It also noted that there is no public transportation to Jebel Qatrani.

In addition, the previous studies mentioned that there is a lack of interpretative information available to visitors and no coordination to ensure geosites management [38,39]. The observation confirmed that there are no pamphlets and brochures in Jebel Qatrani.

In terms of recreational activity, the observation noted that there is a recreational activity such as camping. The literature review confirmed this result that the entertainment industry can be a major supplier to the tourism sector. It is playing a major role in marketing sites and competitive strategy $[3,9]$.

However, the literature review highlighted that medical services are considered one of the main facilitating resources that must be within or near the sites [40]. Also, healthcare must be found inside the protected area to serve the visitor [41]. The study results reported that there is a medical service in Jebel Qatrani.

The goals of geosite development are as follows. It was to develop a greater awareness and understanding of the significant contributions that tourism can make to the environment, people, and the economy, to improve the quality of life of the host community, to provide a high quality of experience for the visitor, and to maintain the quality of the environment [29].

Geotourism sites play an important role in enhancing the living standard of the local community through increasing the chances of work, and the local community would be involved in developing the plan of geosite [33]. 
As well, geosites enhance the local economy through developing the different sorts of productions of the local groups and supporting the income sources for an area's adjacent geosites. It also can strengthen the relationship between the local communities and their land [22,32].

On the other hand, a study revealed that geotourism sites should have shops or outlets to promote its products to the visitors through the making of local handicrafts such as the production of fossil casts and souvenirs by local enterprises [42]. To reduce the poverty, it must be generating sufficient revenue and employment for the local community around the protected area [41].

\section{Site Management and Situational Conditions in Jebel Qatrani}

It is interesting to note that the observation confirmed that there are regulations to protect the environment within Jebel Qatrani. These results matched with the previous study, which said that management strategies in a protected area were directly applied through rules, regulations, and laws enforcement, or indirectly through site design, visitor education, and communication [13]. Direct strategies are often preferred because it is necessary and more effective. Also, it was reported that law enforcement in a protected area is required to support the protection of natural resources and visitors [12].

Geotourism sites should promote its products to its visitors through the making of local handicrafts, such as the production of fossil casts and souvenirs by local enterprises [42]. Geosite should have various recreation activities that help to raise public awareness about the geotourism concept, importance, and value of the site [43]. Also, for the development of geotourism marketing, geological heritage should be linked to educational aims and economic use [13]. On the other hand, marketing gives the ability to attract and satisfy visitors in the site [40]. However, the area of Jebel Qatrani did not have any promotion activities.

Moreover, safety and security concerns can affect the choice of geotourism sites and effects on the demand for geosites. It was reported that it should increase safety and security for visitor and local community around the protected area [41]. Besides, safety and security must be an increase in a protected area, so it should be identifying the visitor ID to achieve that. But, the observation noted that Jebel Qatrani was accessible from all directions. So, anybody can enter at any time and get out at any time without being controlled. There is no accurate count of the visitors' number of the site.

\section{CONCLUSIONS}

The results showed that Jebel Qatrani is characterized by a diversity of natural, geological, and geomorphological features. Also, it showed that geological formations in Jebel Qatrani represent one of the important natural resources because of its great economic value. The results showed that the transportation facilities and accessibility into the Jebel Qatrani are difficult. There is no public transportation to Jebel Qatrani. The observation noticed that there is not pamphlet and brochures in Jebel Qatrani. However, there is a recreational activity such as camping. In addition, there are no shops or places for selling souvenirs to visitors. The observations showed that there is no medical service or ambulance point within or near Jebel Qatrani.

The observation reported that the area of Jebel Qatrani did not have any promotion activities. However, the observation results found the Italian project works in the Open Air Museum in Jebel Qatrani. The observation confirmed this result that Jebel Qatrani was accessible from all directions. So, there is no control over the number of visitors to the site and. It also observed that there is no ticket for entering Jebel Qatrani and a lack of security procedures to protect visitors in Jebel Qatrani.

The study recommended that the local community should be involved in the development strategies of the geosites. They should support the marketing activities of Jebel Qatrani by promoting its products to its visitors through the making of local handicrafts such as the production of fossil casts and souvenirs.

This research has some limitations. First, this research focused on only one case study of Jebel Qatrani. Secondly, the literature showed there had been a clear lack of prior research studies on geotourism site in Egypt, in particularly Jebel Qatrani. Therefore, this research offers several opportunities for potential future research. This research was conducted in one case study. Further research should address more geotourism sites in Egypt. Further research should test the findings of this study with other geotourism sites in Egypt to identify how to generalize the findings. 


\section{REFERENCES}

[1] Armenski, T., D.O. Gomezelj, B. Djurdjev, L. Deri, and D. Aleksandra. 2011. Destination competitiveness: A challenging process for Serbia. Human Geographies 5(1), 19.

[2] Boley, B. B. and R. R. Perdue. 2012. Destination management, competitiveness, and quality-of-life: a review of literature and research agenda. In: Uysal, et al. (Eds). Handbook of Tourism and Quality-of Life Research: Enhancing the Lives of Tourists and Residents of Host Communities, Springer Science Business Media, London. 515-528.

[3] Cracolici, M. F. and P. Nijkamp. 2009. The attractiveness and competitiveness of tourist destinations: A study of Southern Italian regions. Tourism management 30(3), 336-344.

[4] Brilha, J. 2016. Inventory and quantitative assessment of geosites and geodiversity sites: a review. Geoheritage 8(2), 119-134.

[5] Karkola, V., P. Johansson, and J. Seurujärvi. 2015. Golden Geopark of Lapland-defining and evaluating the geological sites. In European Geoparks Conference. September $3^{\text {rd }}-6^{\text {th }}$. Book of Abstracts. Oulu. 27.

[6] Žáček, V., P. Hradecký, P. Kycl, J. Ševčík, R. Novotný, and I. Baroň. 2017. The Somoto Grand Canyon (Nicaragua)-a volcanic geoheritage site one decade after discovery: from field geological mapping to the promotion of a geopark. Geoheritage 9(3), 299-309.

[7] Campón-Cerro, A. M., J. M. HernándezMogollón, and H. Alves. 2017. Sustainable improvement of competitiveness in rural tourism destinations: The quest for tourist loyalty in Spain. Journal of Destination Marketing \& Management 6(3), 252-266.

[8] Ayikoru, M. $2015 . \quad$ Destination competitiveness challenges: A Ugandan perspective. Tourism Management 50, 142158.

[9] Dwyer, L. and C. Kim. 2003. Destination competitiveness: determinants and indicators. Current issues in tourism 6(5), 369-414.

[10] Kim, J. H. 2014. The antecedents of memorable tourism experiences: The development of a scale to measure the destination attributes associated with memorable experiences. Tourism Management 44, 34-45.
[11] Ghiraldi, L., M. Bacenetti, L. Perotti, M. Giardino, and P. Millemaci. 2015. Methodologies and activities to promote geotourism: The case study of the Cannobina Valley (NW Italy). In: Engineering Geology for Society and Territory Vol. 8. Springer, Cham. 269-272.

[12] Premangshu, C. and M. Rahul. 2018. Geotourism mapping for sustainability: a basin oriented approach. GeoJournal of Tourism and Geosites 21(1), 174-185.

[13] Kubalíková, L. 2013. Geomorphosite assessment for geotourism purposes. Czech Journal of Tourism 2(2), 80-104.

[14] Tomić, N. and S. Božić. 2014. A modified geosite assessment model (M-GAM) and its application on the Lazar Canyon area (Serbia). International Journal of environmental research 8(4), 1041-1052.

[15] Abdou, M. Y. K., S. B. Hassan, and G. M. Wafik. 2017. The challenges of geotourism in Egypt: a case study of Wadi AlHitan. International Journal of Hospitality \& Tourism Systems 10(2).

[16] Abdel Maksoud, K. M. and M. G. Hussien. 2016. Geotourism in Egypt and its economic and culture impact. Arabian Journal of Earth Sciences 3(1), 1-13.

[17] Sallam, E. S., E. E. Fathy, D. A. Ruban, A. A. Ponedelnik, and N. N. Yashalova. 2018. Geological heritage diversity in the Fayoum Oasis (Egypt): A comprehensive assessment. Journal of African Earth Sciences 140, 212224.

[18] Sallam, E. S. and D. A. Ruban. 2017. Palaeogeographical type of the geological heritage of Egypt: a new evidence. Journal of African Earth Sciences 129, 739-750.

[19] Reynard, E. 2008. Scientific research and tourist promotion of geomorphological heritage. Geografia fisica e Dinamica quaternaria 31(2), 225-230.

[20] Ruban, D. A. 2017. Geodiversity as a precious national resource: $A$ note on the role of geoparks. Resources Polic 53, 103108.

[21] Ruban, D. A. 2010. Quantification of geodiversity and its loss. Proc. Geologists' Assoc. 121, $326-333$.

[22] Višnić, T., B. Spasojević, and M.Vujičić. 2016. The potential for geotourism development on the Srem Loess Plateau based on a preliminary Geosite Assessment Model (GAM). Geoheritage 8(2), 173-180. 
[23] Sileem, A. H., H. M. Sallam, A. A. Hewaidy, G. F. Gunnell, and E. R. Miller. 2015. Anthracotheres (Mammalia, Artiodactyla) from the upper-most horizon of the Jebel Qatrani Formation, latest early Oligocene, Fayoum Depression, Egypt. Egyptian Journal of Paleontology 15, 1-11.

[24] Simons, E. L. 1990. Discovery of the oldest known anthropoidean skull from the Paleogene of Egypt. Science 247(4950), 1567-1569.

[25] Badawy, H. S. 2018. Termite nests, rhizoliths and pedotypes of the Oligocene fluviomarine rock sequence in northern Egypt: Proxies for Tethyan tropical palaeoclimates. Palaeogeography, Palaeoclimatology, Palaeoecology 492, 161176.

[26] Saunders, M. N. 2011. Research methods for business students, $5^{\text {th }}$ Ed. Pearson Education India.

[27] Collis, J. and R. Hussey. 2013. Business research: A practical guide for undergraduate and postgraduate students. Macmillan International Higher Education.

[28] Bloxam, E. and P. Storemyr. 2002. Old Kingdom basalt quarrying activities at Widan el-Faras, northern Faiyum desert. The Journal of Egyptian Archaeology 88(1), 23-36.

[29] Kubalíková, L. and K. Kirchner. 2016. Geosite and geomorphosite assessment as a tool for geoconservation and geotourism purposes: a case study from Vizovická vrchovina Highland (eastern part of the Czech Republic). Geoheritage 8(1), 5-14.

[30] Serrano, E. and P. Ruiz-Flaño. 2018. Geodiversity: a theoretical and applied concept. Geographica Helvetica 62(3), 140147.

[31] Zorina, S. O. and V. V. Silantiev. 2014. Geosites, Classification of. Encyclopedia of Mineral and Energy Policy, 1-4.

[32] Reynard, E., G. Fontana, L. Kozlik, and C. Scapozza. 2007. A method for assessing "scientific" and "additional values" of geomorphosites. Geographica Helvetica 62(3), 148-158.

[33] Dowling, R. K. 2011. Geotourism's global growth, Geoheritage 3, 1-13.

[34] Štrba, L'., B. Baláž, and M.Lukáč, 2016. Roadside geotourism-an alternative approach to geotourism. E-review of Tourism Research, 13(5/6), 598-609.
[35] Gatley, S. and M. Parkes. 2018. The selection of and characters of a geositeexamples from Ireland. Geoheritage 10, 157-167.

[36] Errami, E., M. Brocx, V. Semeniuk, and N. Ennih. 2015. Geosites, sites of special scientific interest, and potential geoparks in the Anti-Atlas (Morocco), In: Errami, E., M. Brocx, and V. Semeniuk (Eds). From Geoheritage to Geoparks. Springer International Publishing, 57-79.

[37] Marty, D., J. Ayer, D. Becker, J. P. Berger, J. P. Billon-Bruyt, L. Braillard, W. A. Hug and C. A. Meyer. 2007. Late Jurassic dinosaur tracksites of the Transjurane highway (Canton Jura, Switzerland): overview and measures for their protection and valorisation. Bull. für angewandte Geologie 12, 75-89.

[38] Neto de Carvalho, C. and J. Rodrigues. 2009. New challenges with geotourism. In: Proceedings of the VIII European geoparks conference Idanha-a-Nova, $\quad 4^{\text {th }}-6^{\text {th }}$ September, Portugal. 104-108.

[39] Theodosiou, I. 2010. Designation of geosites-proposals for geoparks in Greece. Bulletin of the Geological Society of Greece 43(2), 926-938.

[40] Crouch, G. I. 2007. Modelling destination competitiveness. A survey and analysis of the impact of competitiveness attributes.

[41] Leung, Y. F., A. Spenceley, G. Hvenegaard, and R. Buckley. 2018. Tourism and visitor management in protected areas: Guidelines for sustainability. Gland: IUCN.

[42] Mulec, I. and N. Wise. 2012. Strategic guidelines for the potential geotourism destination Titel Loess Plateau (Vojvodina Region, Serbia), Geoheritage 4, 213-220.

[43] Zouros, N. 2009. Geotourism development in the Lesvos Petrified Forest Geopark. In: Neto de Carvalho, C., and J. Rodrigues (Eds). New challenges with geotourism. Proceedings of the VIII European geoparks conference Idanha-a-Nova, $4^{\text {th }}-6^{\text {th }}$ September, Portugal. 90-93. 